\title{
Studies on type material from Kützing's diatom collection III: Synedra splen- dens (Kütz.) Kütz., Synedra aequalis (Kütz.) Kütz. and a note on Synedra obtusa W.Sm.
}

\author{
David M. Williams ${ }^{1} \&$ Bart Van DE VIJVER ${ }^{2}$
}

\author{
${ }^{1}$ Department of Life Sciences, the Natural History Museum, Cromwell Road, London, SW7 5BD, UK \\ ${ }^{2}$ Meise Botanic Garden, Research Department, Nieuwelaan 38, 1860 Meise, Belgium \& University of Antwerp, \\ Department of Biology-ECOBE, Universiteitsplein 1, 2610 Wilrijk, Belgium
}

\begin{abstract}
Examination of type material for Ulnaria splendens, Ulnaria aequalis and Ulnaria obtusa provides evidence to support each as a distinct and definable taxon. None can be considered more closely related to any other species in the genus Ulnaria and are therefore all recognised at the same rank, that of species. We briefly discuss five further taxa that involve the name Synedra splendens: Synedra splendens var. marina, Synedra splendens var. salina, Synedra splendens var. brevis, Synedra splendens var. subspathulata and Synedra (ulna var.) spathulifera.
\end{abstract}

Key words: Type material; Ulnaria splendens; Ulnaria aequalis; Ulnaria obtusa; SEM

\section{INTRODUCTION}

Ulnaria ulna var. splendens (Kütz.) Aboal (in ABOAL et al. 2003, p. 114, basionym: Frustulia splendens Kütz. $\equiv$ Synedra splendens (Kütz.) Kütz.) and Ulnaria ulna var. aequalis (Kütz.) Aboal (in ABOAL et al. 2003, p. 112, basionym: Frustulia aequalis Kütz. $\equiv$ Synedra aequalis (Kütz.) Kütz.) are often, but not always, considered to be varieties of Ulnaria ulna (Nitzsch) Compère (2001, p. 100, basionym: Bacillaria ulna NiTzSCH 1817, p. 99, pl. 5, figs 1-10, see LANGE-BERTALOT \& UlRich 2014, p. 63 et seq.). Both have previously been known as part of the genus Synedra Ehrenb. (1830, p. 60) but because of nomenclatural problems (see WILLIAMS \& KARTHICK 2021) many of the freshwater species previously placed in Synedra (as re-defined by WiLliams 1986) are now in Ulnaria (COMPÈRE 2001; WILlIAMs 2011).

In addition to being a variety of Ulnaria ulna, Synedra splendens is occasionally understood to be either a synonym of Ulnaria ulna (e.g. PATRICK \& REIMER 1966, pp. 148-149), a 'closely related' but separate species (e.g. Cantonati et al. 2017, p. 603; Lange-Bertalot \& ULRICH 2014, p. 68, "The most closely related taxon of $U$. ulna epitype is apparently Synedra splendens [...]" and CANTONATi et al. 2017, p. 603), or as a complex entity being composed of a number of its own varieties or sub-taxa. The latter option was first explored well over 100 years ago by GRUNOW (1862) and RABENHORST (1864) (their schemes are summarised in Table 1).
At that time, both recognised five sub-divisions within Synedra splendens with some degree of overlap between the two authors (six sub-divisions for Rabenhorst if the nominate variety is included; Grunow considered his var. $[\beta]$ genuina to be equivalent to Synedra splendens). To support his classification, Grunow simply referred to published drawings, either those of Kützing (mostly from KüTzING 1844) or William Smith (mostly from SMITH 1853-56) along with a few cursory notes; Rabenhorst, more helpfully, referred to specimens from various published exsiccata, some published drawings and brief descriptions (Table 1).

Of the taxa that overlapped in the two classifications, both Grunow and Rabenhorst agreed that Synedra aequalis is a variety of (or at least a sub-taxon

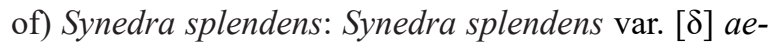
qualis and var. [b] aequalis, respectively. One notable difference between their two classifications is that for Rabenhorst Synedra obtusa W.Sm. (1853, p. 71, pl. 11, fig. 92) was considered to be a synonym of his Synedra splendens var. [b] aequalis, whereas Grunow retained it as a distinct species. Grunow subsequently included S. splendens and all of its varieties, including Synedra obtusa (as Synedra ulna var. obtusa (W.Sm.) Van Heurck 1885, p. 151; VAN HeURCK 1881 pl. 38, fig. 6), under the name $S$. ulna, presumably in an attempt to simplify matters (in VAN HEURCK 1885). It is not necessary in this paper to discuss all the sub-divisions of Synedra splendens offered later by HustedT (1930, 1931, but see 
Table 1. Classifications schemes of Grunow (1862) and RabenHorst (1864) for Synedra splendens and its sub-taxa: $\boldsymbol{\alpha}-\varepsilon$ for Grunow, b-f for Rabenhorst; spelling as in original, double quotes indicate as cited in the publication. Abbreviations: Kg and Ktz. = Kützing (Kütz.); W. Sm. and Smith = William Smith (W. Sm.); Rabenh. = Rabenhorst (Rabenh.); Awd = Auerswald (Auerswald, Bernhard, 1818-1870) (Auersw.); Süssw. Diät. = Die Süsswasser-Diatomaceen (Bacillarien.): Für freunde der Mikroskopie (1853); Alg. N. = Die Algen Sachsens resp. Mittel-Europa's (1848-1860) and Die Algen Europa's (1861-1874); Desmaz. = Desmazières, Plantes cryptogames de la France, edition I and II.

GRUNOW (1862)

\begin{tabular}{|c|c|c|}
\hline Synedra splendens & p. 394 & \\
\hline var. $[\alpha]$ longissima & p. 395 & $\begin{array}{l}\text { = "Synedra biceps Kg..." [P1. 14, fig. XVIII and P1. XXI, fig. 1] } \\
\text { "Synedra biceps Rabenh. Süssw. Diät. V. S. 9. [= Tab. V, fig. 9, see p. 55]" } \\
\text { "Synedra longissima Sm" }\end{array}$ \\
\hline var. $[\beta]$ genuina & p. 395 & $=$ "Synedra splendens Kg." \\
\hline var. $[\gamma]$ danica & p. 396 & = "Synedra danica Kg." \\
\hline var. $[\delta]$ aequalis & p. 396 & = "Synedra aequalis" \\
\hline var. $[\varepsilon]$ obtusa & p. 397 & $=$ "Synedra obtusa Smith" \\
\hline
\end{tabular}

RABENHORST (1864)

\begin{tabular}{|c|c|c|}
\hline Synedra splendens $[=\mathrm{a}]$ & p. 134 & "Alg. N. 548 et sub No 1082" \\
\hline var. [b] aequalis & p. 134 & $\begin{array}{l}=\text { "Synedra aequalis" } \\
=\text { "Synedra obtusa Smith" } \\
\text { "Rabenh. Alg. N. 1202" }\end{array}$ \\
\hline var. [c] debilis & p. 134 & $\begin{array}{l}=\text { "Synedra danica Ktz." } \\
\text { "Rabenh. Alg. sub 1063" }\end{array}$ \\
\hline var. [d] vitrea & p. 134 & $\begin{array}{l}=\text { "Synedra vitrea Ktz." } \\
\text { "Desmaz. ed. I. N. 1458, ed. II. N. 1058" (See Williams 2019a) }\end{array}$ \\
\hline var. [e] interrupta & p. 134 & $=$ "Synedra interrupta Awd in Rabenh. Alg. N. 403" \\
\hline var. [f] aggregata & p. 134 & $=$ "Synedra aggregata Bréb. in Rabenh. Alg. N. 687" \\
\hline
\end{tabular}

below under Ulnaria obtusa) as almost everything noted by Grunow and Rabenhorst ended up as a sub-taxon of Synedra ulna (HustedT 1930, p. 152) probably following Grunow's later classification, or at least partially inspired by it (in VAN HeURCK 1885, pp. 150-151).

Given the viewpoint that varieties (a rank) as sub-taxa of species, etc. have no particular meaning other than being a sub-division of a species (a higher rank), a more reasonable way of approaching an understanding of Synedra splendens and its apparent sub-groups is to first examine and describe the relevant types, their diagnoses and descriptions. For other species in the genus Ulnaria, this strategy has already been adopted beginning with some types first described by Kützing as herbarium material is available and the specimens are of particularly good quality (see WiLLIAMs 2019a; WiLliams \& BlANCO 2020).

For Synedra splendens, as understood by GRUNOw (1862) and Rabenhorst, eight names (hence eight types) are of immediate interest. Alongside Synedra splendens itself, as well as $S$. aequalis and S. obtusa (mentioned above), there is $S$. biceps Kütz., S. longissima W.Sm., $S$. danica Kütz., S. vitrea Kütz., S. interrupta Auersw. (in RABENHORST 1855, no. 463) and S. aggregata Bréb. (in
RABENHORST 1858, no. 687). Of those eight, five have already been transferred to Ulnaria either as species or varieties of other species (most frequently ulna), but none, as far as can be determined, were based on an examination of type material (Table 2).

This contribution presents details of the type specimens for Synedra aequalis, S. splendens and, because of the apparently confusing taxonomy and nomenclature, the latter discussed by REICHARDT (2018, see below), and its equivocal position in the classifications of Grunow and Rabenhorst, some observations and comments are necessary on the type specimens of Ulnaria obtusa (W.Sm.) E.Reichardt (basionym: Synedra obtusa W.Sm. 1853, p. 71, pl. 11, fig. 92). Synedra vitrea has been dealt with elsewhere (WILliams 2019a), Synedra biceps and Synedra danica will be the subject of separate studies, as will be Synedra interrupta and Synedra aggregata Bréb..

\section{Material ANd Methods}

As all the materials examined in this study are appended to each species description below, a separate section detailing 
Table 2. The eight names of species in Synedra included at one time or another as sub-taxa of Synedra splendens by Grunow (in 1862) and Rabenhorst (column 1) with their equivalent name as used in Ulnaria (column 2); five names are now in Ulnaria, three are not (*); many of these names were 'mechanical' transfers made on the basis that if Synedra ulna was now a species of Ulnaria then its varieties should be so as well.

\begin{tabular}{ll}
\hline \multicolumn{1}{c}{ Synedra } & Ulnaria \\
\hline Synedra aequalis & Ulnaria ulna var. aequalis (Kützing) Aboal \\
Synedra aggregata* & Ulnaria biceps (Kützing) Compère \\
Synedra biceps & Ulnaria danica (Kützing) Compère et Bukhtiyarova \\
Synedra danica & Ulnaria ulna var. danica (Kützing) Harper in Harper et al. \\
Synedra interrupta* & \\
Synedra longissima* & \\
Synedra obtusa & Ulnaria obtusa (W.Sm.) E.Reichardt \\
Synedra vitrea & Ulnaria vitrea (Kützing) E.Reichardt \\
\hline
\end{tabular}

the specimens was considered to be superfluous.

Author names are abbreviated according to International Plant Name Index, https://www.ipni.org/index.html and, for the most part, valve and girdle terminology follows accepted conventions. Herbarium abbreviations follow Index Herbariorum (http:// sweetgum.nybg.org/science/ih/).

Many herbaria now have digital access to their specimens. We have included hyperlinks to the specimens when they are available (for $\mathrm{L}$ and $\mathrm{BM}$ ).

\section{TAXONOMIC TREATMENTS}

\section{Ulnaria splendens (Kütz.) D.M.Williams et Van de Vijver, nov. comb. \\ Basionym: Frustulia splendens Kütz. in KüTZING (1833a), Linnaea 8} (5), p. 553, fig. 23 [1833 (1834), p. 25, taf. II, fig. 23, see our Figure 8], (1833b), [p. 3], no. 73; KüTZING (1833a), Taf. XIV, fig. 23 = KüTZING 1833 (1834), taf. II, fig. 23 (same figure), lectotype, designated here. Synonyms (homotypic): Synedra splendens Kütz. in KüTZING 1844, p. 66, pl. 14, fig. 16; Synedra ulna var. splendens (Kütz.) Van Heurck in VAN HeURCK 1885, p. 150 (pl. 38, fig. 2 = "S. (ulna var.) longissima W.Sm. forma area media laevi destituta"); Ulnaria ulna var. splendens (Kütz.) Aboal in ABOAL et al. (2003, p. 114).

Type: Germany, Weissenfels [Weißenfels]: "In kleinen klaren Bächen an Wasserpflanzen [...] bei Weissenfels, Schleusingen [In small clear brooks on aquatic plants [...] at Weissenfels [Weißenfels], Schleusingen]" (KÜTZING 1833a, p. 553); "In rivulis ad plantas aquaticas prope Leucopetram [=Weissenfels]" (KüTZING 1833b, [p. 3], no. 73), BM 18279! (KüTZING 234, = original material, "1833”]), epitypes designated here, BM 18271! ("Weissenfels [KüTZING] 182", see Cox (1998, p. 167); also BM 18273! (KüTZING 181) and BM 18281! (KüTZING 183) both from Weissenfels; Dresden, RABENHORST [KÜTZING 233], BM 18276

Other material: France: Falaise, BM 18272! [KüTZING 10971, "Exilaria splendens Breb.", nom. herb.], BM 18275! [KüTZING 10941, "Exilaria splendens Breb.", nom. herb.], BM 18274! [KÜTZING 1397'], BM 18277 ! [“Côtes de Calvados", KüTZING 1221'], BM 18280! [KüTZING 1226']; BM 18282! [KüTZING 13941], L. 4020180, "Falaise", L.4020160, L.4020173 , L.4020146 , L.4020172 ; L.4020182, "Vire"; Netherlands:

1 There are no notebook entries for these numbers.
BM 18278! (KÜTZING 156, “1846 v.D. BosCH”, see VAN DEN BoSCH 1846, p. 85); L.4111639 “Goes V.D. Bosch 243”.

Valves linear, margins tapering at both poles (Figs 1-10); valves 60-300 $\mu \mathrm{m}$ long, 5-10 $\mu \mathrm{m}$ wide. Sternum narrow, linear, uniform, extending length of valve (Figs 1-10, 18). Central area present, formed by shortening of several marginal striae creating a round to oval hyaline portion (Figs 1-7, 11). Striae formed from relatively wide virgae, adjoining smaller (relative to virgae) vimines, enclosed by a 2 - to 4 -strutted closing plate, almost always opposite each other relative to sternum, except (occasionally) at poles (Figs 1-7, 10, 11, 18); 6-10 striae in $10 \mu \mathrm{m}$. Rimoportula at each pole, oriented diagonally, situated from sternum to virgae (Fig. 18), composed of paired lips (Figs 10, 18). Ocellulimbus at each pole, situated entirely on mantle (Fig. 17), composed of ca. 10-15 transapical rows with 10-12 pervalvar rows, and 2 horn-like projections ('spines', cf. WiLliams 2019b) overhanging ocellulimbus, at an angle of c. $30^{\circ}$ away from valve surface (Fig. 17). No other spines; mantle exterior with plaques (Figs 15, 16). Cingulum of total 2-3 closed bands: valvocopula plus 1-2 copulae (Figs 12, 14, 16). Valvocopula with deep pars interior, same size as pars exterior, the latter having a series of 6- to 10-strutted closing plates (Figs 13 and 14, arrows) situated at its edge but visible when observed in situ (Figs 12-14, 16); pars interior smooth with undulating extensions of pars interior that affix to valve interior gripping each vimen (Figs 12, 14, 16).

Although original material of Ulnaria splendens was examined, these specimens are designated epitypes with respect to the drawing, which is here designated as lectotype. The primary reason for assigning epitypes is that Kutzing's drawings can be, and have been, ambiguously interpreted.

It is difficult, if not impossible, to assess the distribution of Ulnaria splendens as very many records may turn out to be erroneous. We suggest that, for the 

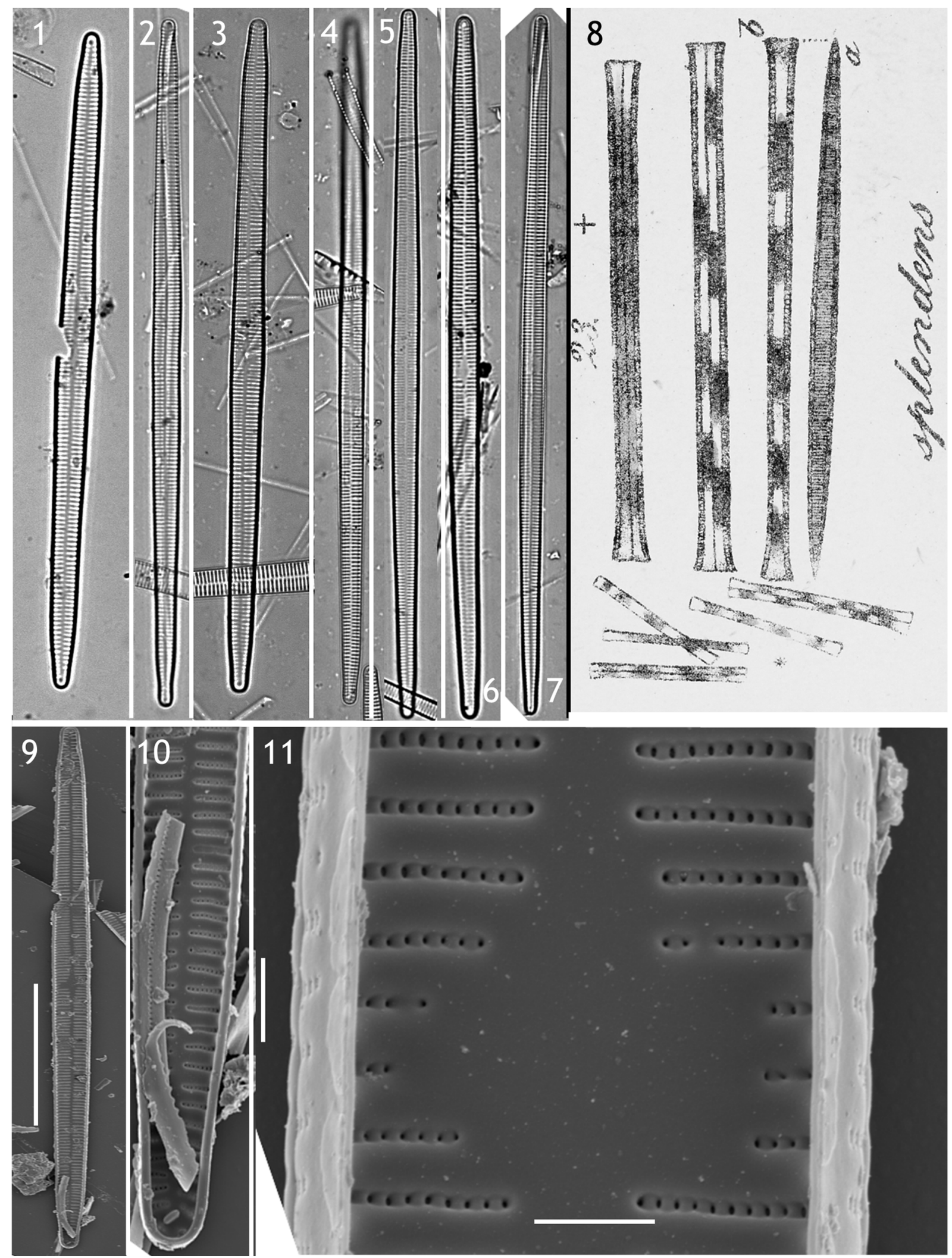

Figs 1-11. Ulnaria splendens (Kützing) D.M.Williams et Van de Vijver, nov. comb.: (1-7) light micrographs from BM 18279 (Kützing 234 , = original material, “1833”); (8) reproduction of Kützing 1833a, taf. XIV, fig. 23 = Kützing 1833 (1834), taf. II, fig. 23, lectotype, designated here; (9-11) SEM images of type material, (9) whole valve, (10) detail of pole, (11) details of central area. Specimens c. $80-150 \mu \mathrm{m}$. 

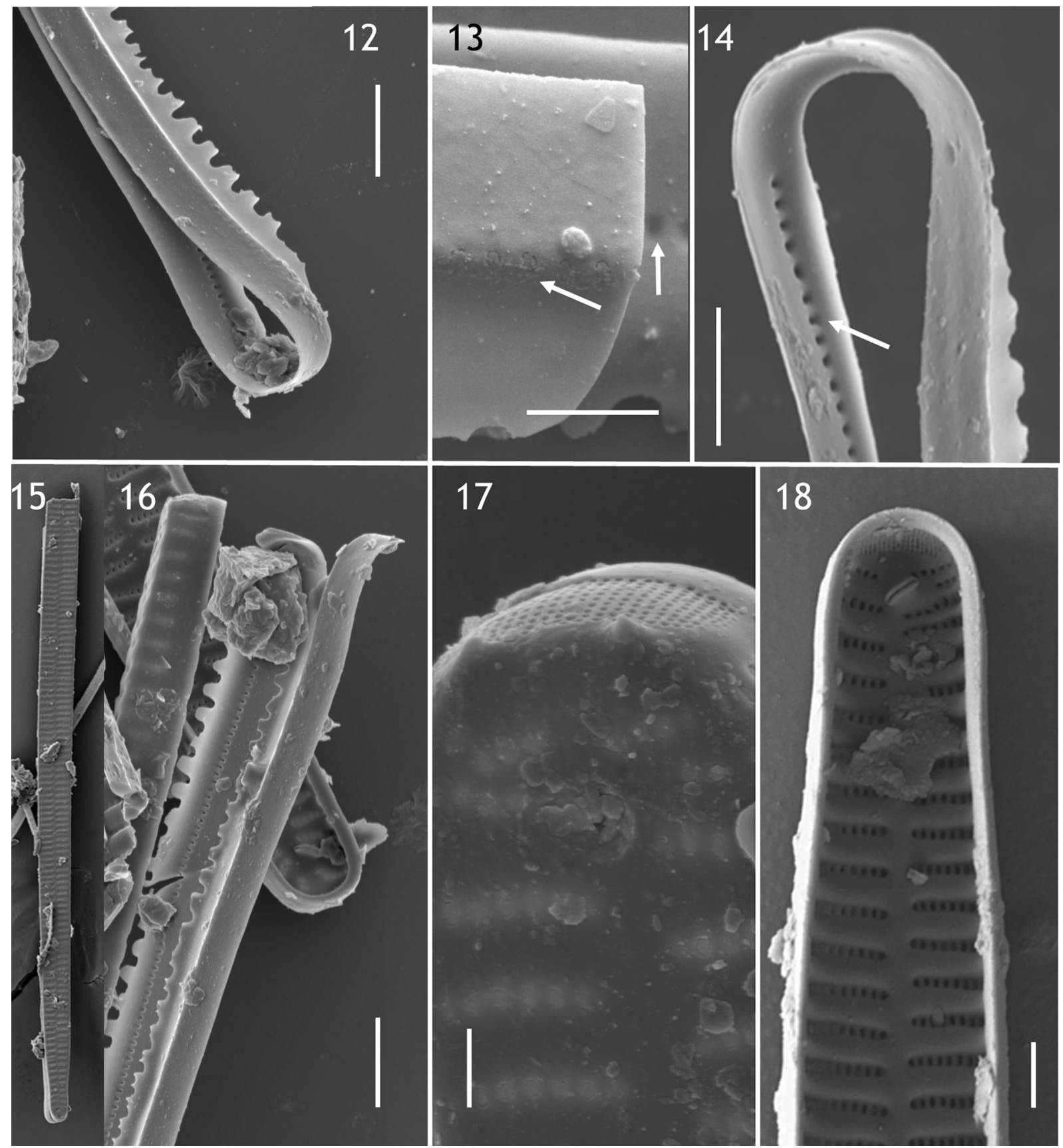

Figs 12-18. Ulnaria splendens (Kützing) D.M.Williams et Van de Vijver, nov. comb.: $(12-14)$ girdle bands, $(12,16)$ with with undulating extensions of pars interior; arrows on $(13,14)$ indicating strutted closing plates; $(17)$ with ocellulimbus, (18) with rimoportula at an angle relative to virgae. Scale bars for Figs 1-18: $10 \mu \mathrm{m}(9,15), 5 \mu \mathrm{m}(10), 2 \mu \mathrm{m}(11,12,14,16,18) ; 1 \mu \mathrm{m}(13,17)$.

moment, its distribution can be considered European even though there exists records outside that continent, often under one or another of its synonyms.

According to Patrick (in PAtrick \& ReImer 1966, p. 149), it was Ehrenberg who first suggested that the names Ulnaria ulna and Ulnaria splendens referred to the same species (EHRENBERG 1838, p. 211), noting that "Certainly from Kützing's Dec. VIII, no. 73, Dec. I, no. 1 they are probably the same taxon, although there is considerable variation in the shape of the apices of the valve" (PATRICK in PATRICK \& ReIMER 1966, p. 149). This comment refers to two separate exsiccatae from Kützing's Algarum aquae dulcis Germanicarum (KüTZING 1833b): the first, Decas VIII, no. 73, studied here, is type material of Frustulia splendens; the second, Decas I, no. 1, is said to be of Frustulia ulna, which Kützing declared himself as author (but also notes that his name is based on Bacillaria ulna Nitzsch), also from Weissenfels [Weißenfels]. These specimens have not been examined in detail but there are quantifiable differences between the specimens of Frustulia splendens (Decas VIII, no. 73, illustrated here) and Frustulia ulna sensu KÜTZING (Decas I, no. 1, pers. obs. and http://clade.ansp. org/cache/images/dh/TYPES/KutzingI_FrustuliaUlna/ 
KutzingDecas1_1_FrUlna_1a_ed.jpg). LANGE-BERTALOT \& UlRICH (2014) also note that "Frustulia splendens Kütz. [...] appears as the morphologically closest related [i.e., similar] to Bacillaria ulna [...] being up to ca. $370 \mu \mathrm{m}$ long, $8 \mu \mathrm{m}$ broad, in valve view tapering to not protracted, acutely rounded ends with a central area and 7-8 striae in $10 \mu \mathrm{m}$ " (LANGe-Bertalot \& Ulrich 2014, p. 63). Oddly enough, neither Kützing's Frustulia splendens nor Frustulia ulna really compare favourably to the specimens selected as epitypes by LANGE-BERTALOT \& Ulrich (2014, pl. 28, figs 1-2). Thus, the examination of and identity of Kützing's Frustulia ulna specimens remains a task still to be undertaken.

Van Heurck, at first, named (or described) the taxon " $S$. (ulna var.) longissima W.Sm. forma area media laevi destituta" (VAN HEURCK 1881, pl. 38, fig. 2), but later included the specimen in his account of Synedra ulna var. splendens (Kütz.) Van Heurck (VAN HEURCK 1885 , p. 150) and noted in the description several 'types' from the Types du Synopsis des Diatomées de Belgique set of slides: "in Types $\mathrm{N}^{\text {os }} 312,15.107$. etc." (VAN HEURCK 1885, p. 150). The phrase "area media laevi destituta" appended to the species name cannot be considered a proper taxon name and, for nomenclatural purposes, can be disregarded (Art. 23.6). The 'types' in Van Heurck's Types du Synopsis des Diatomées de Belgique for Synedra splendens are listed in Table 3. There are 18 in all, some of which are named as Synedra ulna var. splendens, others simply as Synedra splendens. Types 15, 107 and 312, named as having "S. (ulna var.) longissima W.Sm. forma area media laevi destituta", are all named as Synedra splendens. In the annotated copy of Van Heurck's Synopsis des Diatomées de Belgique (preserved in Vienna, W), the relevant figure (VAN

Table 3. The 'types' for Synedra splendens in Van Heurck's Types du Synopsis des Diatomées de Belgique (1882-1885); there are 18 slides in all for Synedra splendens and Synedra ulna var. splendens - with two additional slides for Synedra splendens var. subspathulata (see later) and Synedra splendens f. ["formae breviores"]. Types 15, 107 and 312 (indicated with a * are identified by Van Heurck as having "S. (ulna var.) longissima W. Sm. forma area media laevi destituta" (VAN HeURCK 1885, p. 150)". Locality details taken from the printed schedules of the Types du Synopsis des Diatomées de Belgique, information in square brackets from the cards included with the Types du Synopsis des Diatomées de Belgique slide boxes.

Types du Synopsis des Diatomées de Belgique

\begin{tabular}{|c|c|c|}
\hline Number & Name & Locality \\
\hline $15^{*}$ & Synedra splendens & "Anvers" ["Belgique"] \\
\hline 16 & Synedra splendens var. & $\begin{array}{l}\text { "Dépot fossile (Kieselguhr) d'Oberohe près } \\
\text { Lunebourg" ["Allemagne"] }\end{array}$ \\
\hline 19 & Synedra splendens v.v. & "Devizes (Angleterre)" [“Angleterre"] \\
\hline 24 & Synedra splendens var. & "Wedel (Holstein)" [Holstein"] \\
\hline 25 & Synedra splendens var. [?] subspathulata & "Deurne près Anvers" [Belgique] ${ }^{1}$ \\
\hline $107^{*}$ & Synedra splendens & "Bruxelles (Belgique)" [Belgique] \\
\hline 132 & Synedra splendens var. & "Finnety, (Angleterre)" [“Angleterre"] \\
\hline 190 & Synedra splendens & “Etang du Parc à Anvers (Belgique)" [Belgique] \\
\hline 206 & Synedra (ulna var.) splendens formae breviores & “Anvers (Belgique)" [Belgique] \\
\hline 214 & Synedra (ulna var.) splendens & "Devizes (Angleterre)" [“Angleterre”] \\
\hline 249 & Synedra splendens & $\begin{array}{l}\text { "Tamise, près Great Marlone (Angleterre)" ["An- } \\
\text { gleterre"] }\end{array}$ \\
\hline 258 & Synedra splendens & "Devizes (Angleterre)" [“Angleterre"] \\
\hline 269 & Synedra splendens & “...Haverfordwest (Angleterre)" [“Angleterre"] \\
\hline $312 *$ & Synedra splendens & "Bruxelles (Belgique)" ["Belgique"] \\
\hline 313 & Synedra splendens & "Sandheim" ["Allemagne"] \\
\hline 332 & Synedra splendens & "Redesdale (Angleterre)" [“Angleterre"] \\
\hline 337 & Synedra splendens & "Nieuport (Belgique)" ["Belgique"] \\
\hline 461 & Synedra splendens & "Braemar (Angleterre)" ["Angleterre"] \\
\hline
\end{tabular}

(Footnotes)

1 See Howard et al. (2019) and the discussion below. 
HeurCK 1881, pl. 38, fig. 2) is marked "Kütz. Alg. aq. dulcis 73", meaning Kützing's Algarum aquae dulcis Germanicarum, Decas VIII, no. 73 (KüTZING 1833b).

\section{A note on Synedra splendida Ehrenberg and 'Synedra splendida Ptschelin'}

Synedra splendida Ehrenb.: Possibly confused with Synedra splendens Kütz., at least nomenclaturally, Ehrenberg listed a species named Synedra splendida from various localities. Ehrenberg's early uses of the name (EHRENBERG 1849a, p. 83, 87, 194; EHRENBERG 1854, p. 39 ) are all nomen nudum, but a later publication included a full description and figure (EHRENBERG 1871, p. 59, pl. III, 2, fig. 3, see our Figs 19-21). Although his drawing is not entirely uninformative, it might be interpreted as either a valve from a species of Nitzschia (see DE ToNi 1892, p. 668) or Ulnaria, the former more likely (Fig. 19 = EHRENBERG 1871, pl. III, 2, fig. 3; Fig. $20=$ Ehrenberg's original drawing 1183,). Examination of Ehrenberg's actual specimen suggests it is a Nitzschia (Fig. 21, holotype specimen, BHUPM 241012). Although it may seem unnecessary to attempt to clarify Ehrenberg's specimen, doing so means it is not lost from the record entirely. A brief summary of its nomenclature is as follows:
Nitzschia splendida (Ehrenb.) D.M.Williams et Van de Vijver, nov. comb.

Basionym: Synedra splendida Ehrenb. in EHRENBERG 1871, Abhandlungen der Königliche Akademie der Wissenschaften zu Berlin 1870, 43, p. 59 (66), Pl. III, 2, fig. 3 ('In stratis Oregonicus ad Fallriver fragmenta observata sunt'); EHRENBERG 1849a, p. 83, 87 ('Oregon', nom. nud.), 1849b, p.194 ('gypslager in Klein-Asien', nom. nud.); EHRENBERG 1854, p. 37 ('Braungrauer Mergel-Sand von Siwas im altern cappadocien', nom.nud.)
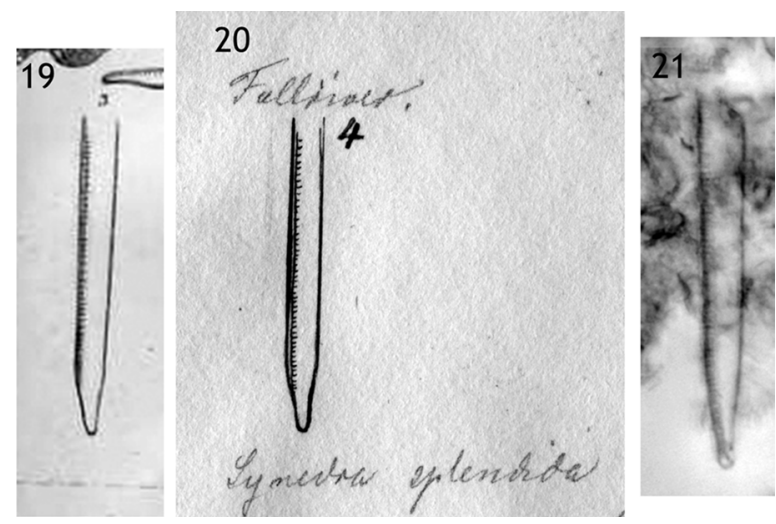

Figs 19-21. Nitzschia splendida (Ehrenberg) D.M.Williams et Van de Vijver, nov. comb.: (19) reproduction of the original description of Synedra splendida Ehrenberg (1871, p. 59); (20a) reproduction of drawing of Synedra splendida Ehrenberg (1871, pl. III, 2, fig. 3), (20b) Ehrenberg's original from EC 1183), (21) Ehrenberg's holotype specimen (BHUPM 241012).

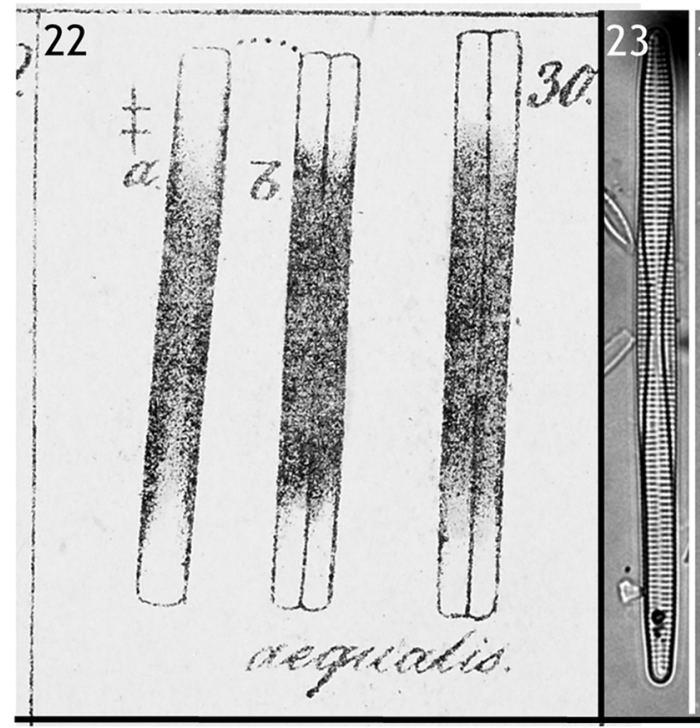

28 28. FRUSTUlia AEQUALIS. Ktz. (Fig. 30.) Frustulis prismaticis, truncatis, longioribus, lutescentibus, apice hyalinis.

Unter Frustulia pellucida ziemlich selten. - Sie bewegte sich. Man hat sich bei dieser vorzusehen, dass man sie nicht mit Frustulia Ulna oder einer ähnlichen verwechselt; man erkennt sie leicht daran, dass sie von der Seite besehen nicht wie jene zugespitzt ist.
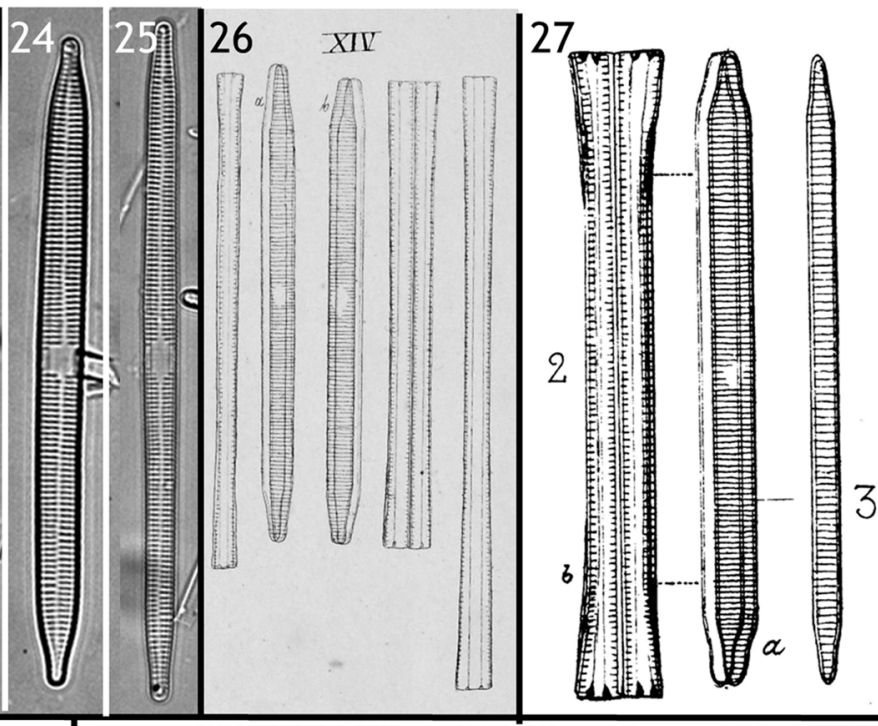

29 39. SYNEDRA AEQUALIS. Taf. 14. Fig. XIV. $\left({ }^{42^{\circ}}\right)$. S. major, linearis, a latere primario utrinque dilatata, a latere secundario apice subattenuato obtuso-rotundato.

Frustulia aequalis $K g$. Syn. p. 18.

In stehendem Wasser bei Weissenfels. -

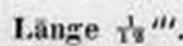

Figs 22-43. Ulnaria aequalis (Kützing) D.M. Williams et Van de Vijver, comb. nov.: $(22-29),(22,28)$ original drawing and description of Frustulia aequalis Kützing (1833a, p. 546, pl. 14, fig. 30 = KüTZING 1834 [1833], p. 18, taf. II, fig. 30); (23-25) specimens from BM 18267 ("Weissenfels" [Kützing 226], neotype designated here); (27) original drawing of Synedra ulna var. aequalis (Kützing) Brun (1880, p. 126, pl. 5, figs 2, 3). Specimens c. 80-100 $\mu$ m. 


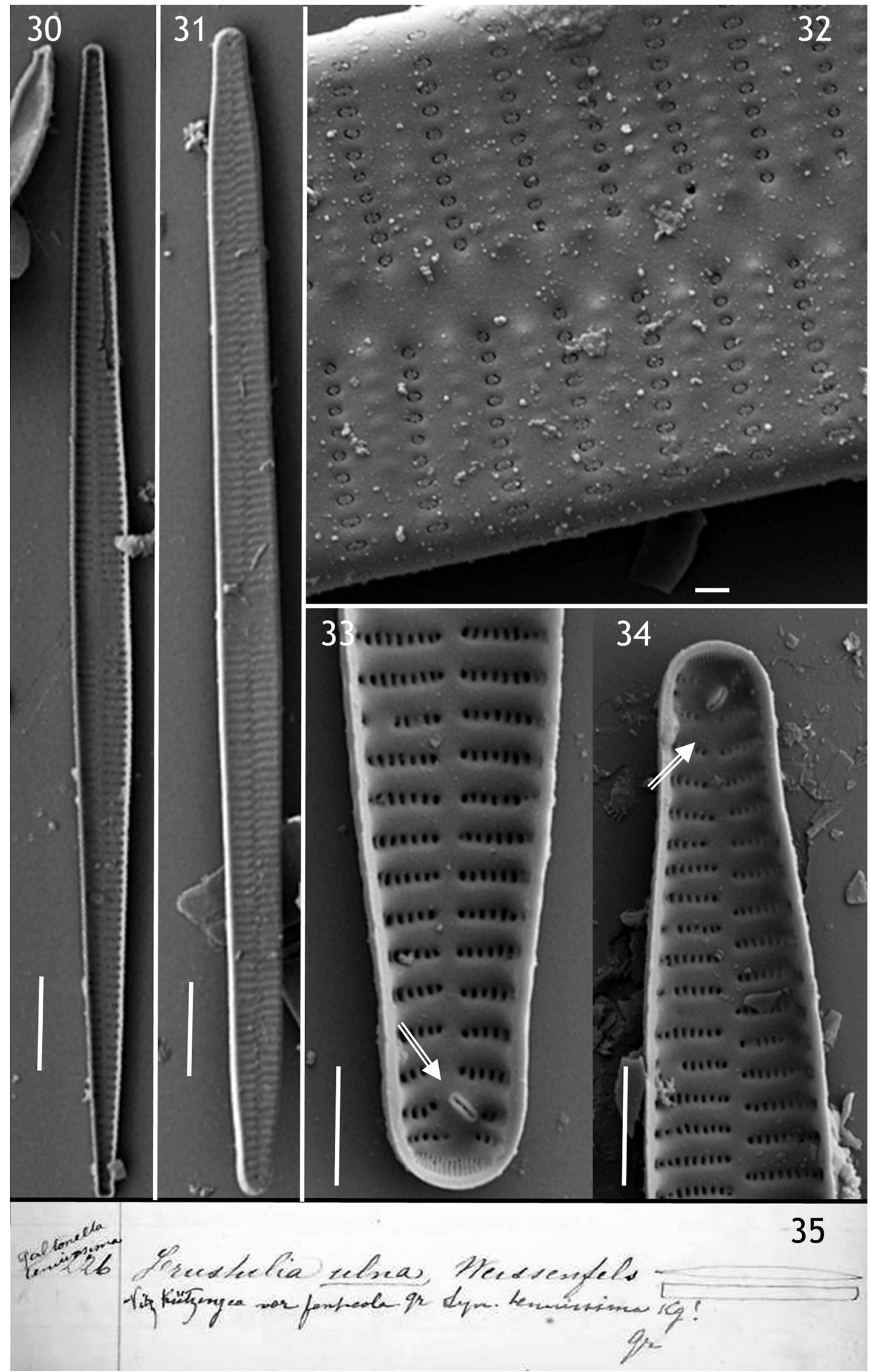

Figs 30-35. Ulnaria aequalis, scanning electron micrographs from type material: $(30,31)$ whole valve, internal (30), and external (31); (32) detail of external valve surface with virgae, vimines and closing plates, and central sternum; $(33,34)$ internal view of each pole, with rimoportula at an angle relative to virgae (arrow in each case); (35) extract from notebook detailing type material ("Weissenfels" [Kützing 226]). 
Type: USA, Fall River, Oregon (Ehrenberg 1871, p. 59, Pl. III, 2, fig. 3, holotype specimen BHUPM 241012, 'Fallriver' (Drawing 1183, '...Fallriver fragmenta...' ['Fallriver'],).

'Synedra splendida Ptschelin': The name 'Synedra splendida Ptschelin (PTSCHELIN 1930)' was recorded by VANLANDINGHAM (1978, p. 3942) who cited HolLERBAKH \& Krasavina (1971, p. 563) as the source of the Ptschelin (1930) reference. HollerbaKH \& Krasavina (1971, p. 563) refer to reference number 1645 for the name Synedra splendida (as opposed to the many entries for Synedra splendens). This reference is to ProschKInALAVRenko \& Roll (1927). The 'Ptschelin (1930)' reference in HollerbaKH \& Krasavina (1971, p. 563) refers to number 1645-a. A copy of the 'PTSCHELIN (1930)' reference has not yet been located but inspection of ProschKina-LAVRENKo \& Roll (1927) yields just one occurrence of the name 'Synedra splendida'
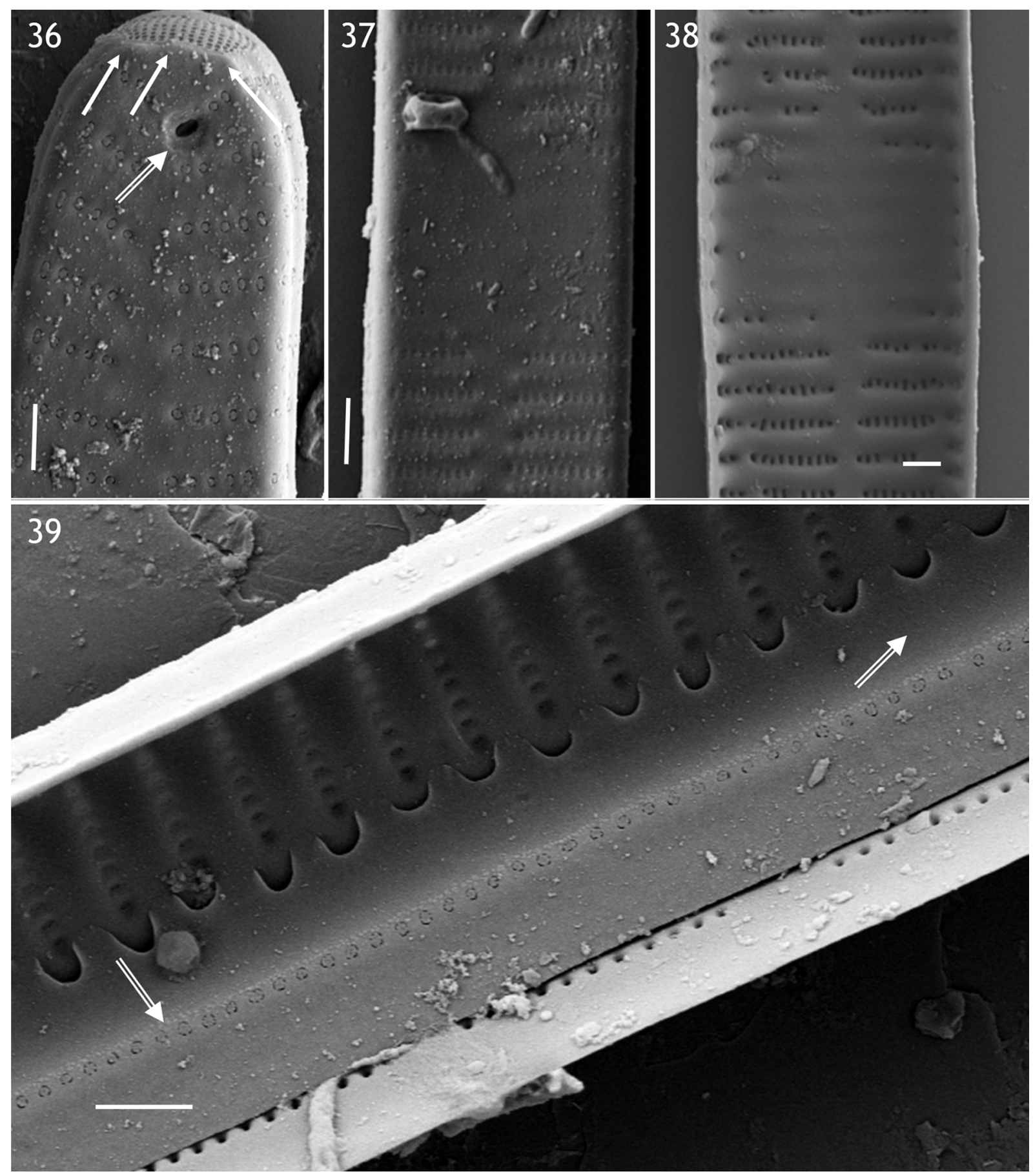

Figs 36-39. Ulnaria aequalis, scanning electron micrographs from type material: $(36,37)$ external view of pole (36) and central area (37), pole with ocellulimbus situated on mantle, with over-hanging spines (arrows), and rimportula (double-margined arrow), central area demarcated by the absence of vimines; (38) as 'ghost striae, internally; (39) internal view of valve with slightly displaced valvocopula showing 'poroids' along pars interior edge (double arrow) and crenulated edge for attachment to valve virgae. 
and it is attributed to Kützing (ProschKINA-LAVRENKO \& RoLl 1927, p. 123). We suspect that this is what was recorded by HollerbaKH \& KRASAVINA (1971, p. 563) and inadvertently mis-transcribed by VANLANDINGHAM (1978, p. 3942). In turn, we suggest that there is no species with the name 'Synedra splendida Ptschelin'.

\section{Ulnaria aequalis (Kütz.) D.M. Williams et Van de Vijver, nov. comb.}

Basionym: Frustulia aequalis Kütz. in KüTZING 1833a, Linnaea 8 (5), p. 546, pl. 14, fig. 30 (KüTZING 1834 [1833], p. 18, taf. II, fig. 30, see our Figures 22 and 28).

Synonyms (homotypic): Synedra aequalis (Kütz.) Kütz. in KüTzING 1844, p. 66, pl. 14, fig. 14 (see our Figures 26 and 29); Synedra ulna var. aequalis (Kütz.) Brun in BRUN 1880, p. 126, pl. 5, figs 2, 3 (see our Figure 27) non Synedra ulna var. aequalis (Kütz.) Hust. in HustedT 1914, p. 44 [nom. superfl.]; Ulnaria ulna var. aequalis (Kütz.) Aboal in ABOAL et al. 2003, p. 112.

Type: Germany: "In stellendem Wasser bei Weissenfels" (KüTZING 1844, p. 66), BM 18267 ("Weissenfels", KÜTZING 226, neotype designated here, see Figure 35), BM 18242 ("Weissenfels", [no.] KüTZING 226, as Synedra ulna) (see also Cox 1998, p. 167).

Other material: Italy: Tergesti [=Trieste] ex MENEGHINI BM 18266 (KÜTZING 942); France: Falaise, BRÉBISSON BM 18268 (KüTZING 1581).

Valves linear, parallel sides tapering at poles (Figs 23-25, 30, 31, 33, 34); valve 50-200 $\mu \mathrm{m}$ long, 5-10 $\mu \mathrm{m}$ wide.
Sternum narrow, linear, extending length of valve (Figs 23-25, 30-34). Central area sometimes lacking, when present with shorter marginal striae forming rectangular portion (Figs 23-25, 30, 37, 38). Striae formed from relatively wide virgae, adjoining considerably smaller vimines, enclosed by a 2 - to 4 -strutted closing plate (Fig. 32), almost always found opposite each other relative to sternum, except (occasionally) at poles (Figs 32-34, 36-38); 4-6 striae in $10 \mu \mathrm{m}$. Rimoportula at each pole, oriented diagonally, situated from sternum to virgae, formed of paired lips (Figs 33, 34, 36, double-margined arrow). Ocellulimbus at each pole, situated entirely on mantle, composed of ca. 12-15 transapical rows with 10-12 pervalvar rows, 2 horn-like projections ('spines', cf. WiLliams 2019b) overhanging ocellulimbus, at an angle of $30^{\circ}$ away from valve surface (Fig. 36, arrows). No other spines; mantle exterior with plaques (Fig. 32). Girdle bands closed (Figs 40-43, 42 and 43 of the same band), total number in cingulum undetermined, probably three. Valvocopula with deep pars interior, same size as pars exterior, having a series of 6- to 10-strutted closing plates situated at its edge but visible when observed in situ (Figs 39-43, arrow in Figs 39, 41, 43); pars interior smooth with undulating extensions that affix to valve interior gripping each vimen (Figs 39, 41-43).
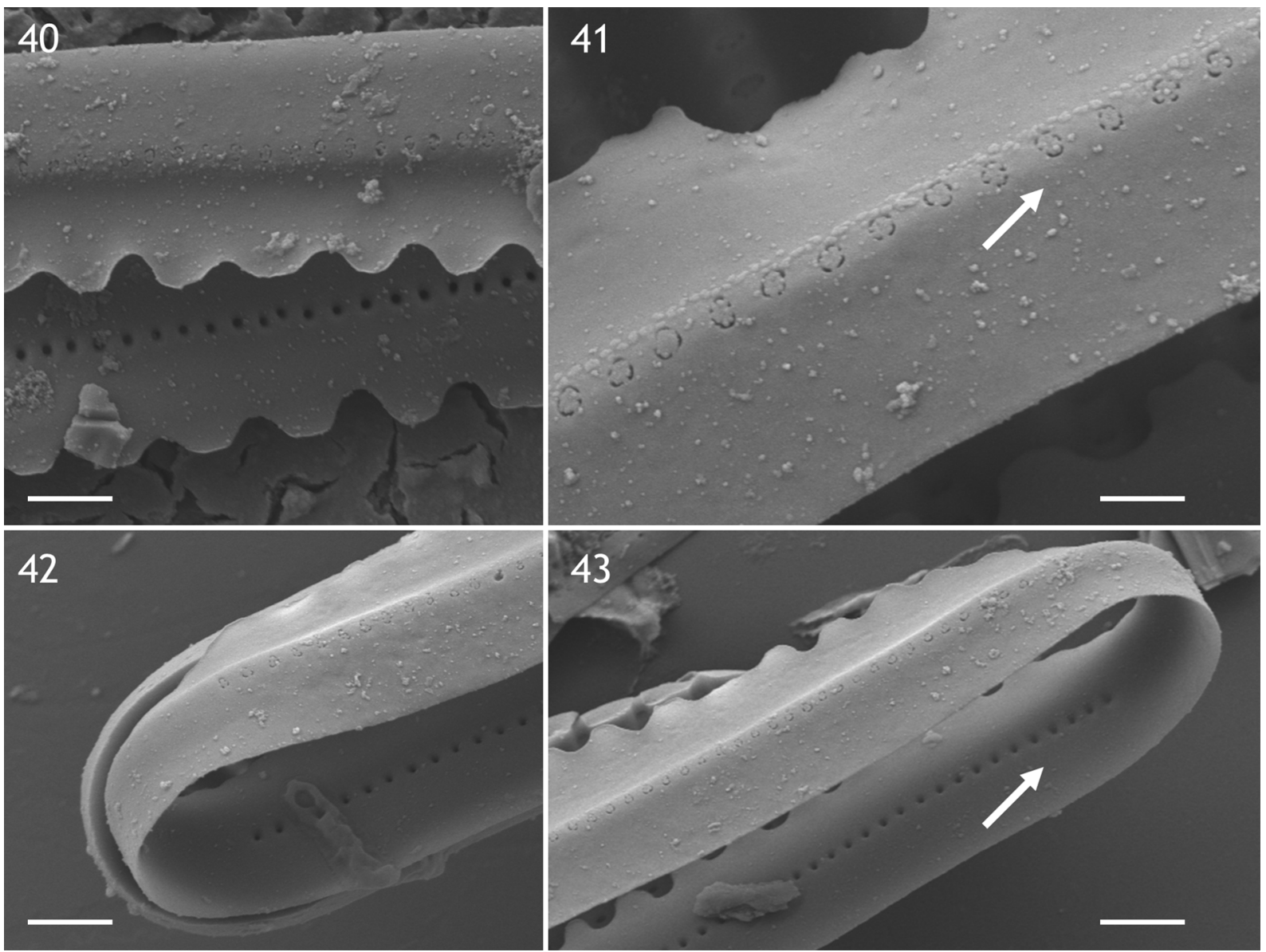

Figs 40-43. Ulnaria aequalis, scanning electron micrographs from type material. All figures of girdle bands showing 'poroids' along pars interior edge (arrows in 41, 43) and crenulated edge for attachment to valve virgae. Scale bars for Figs 30-43: 10 $\mu \mathrm{m}(30,31)$, 1 $\mu \mathrm{m}(32,40,41$, $42,43), 2 \mu \mathrm{m}(33,34,37,38), 5 \mu \mathrm{m}(36,39)$. 


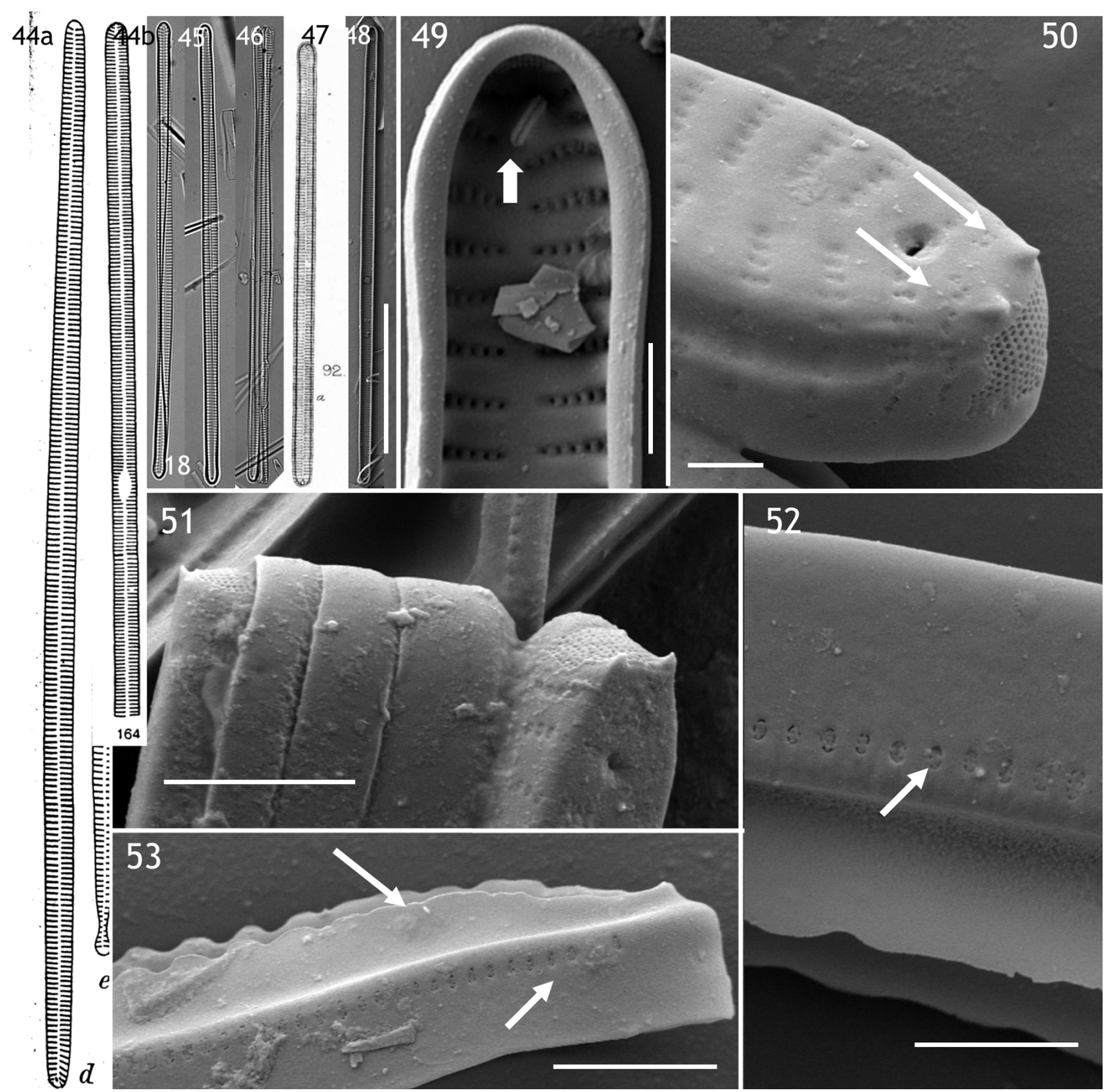

Figs 44-53: Ulnaria obtusa (W.Sm.) E. Reichardt: (44a) Synedra obtusa reproduced from HustedT (1932, p. 199, fig. 691 Ad); (44b) Synedra obtusa reproduced from HusteDT $(1930$, p. 152, fig. 164); $(45,46,48)$ light micrographs from BM 23750, "Lewes, Feb. 1852"; (47) Synedra obtusa reproduced from SMITH 1853, pl. 11, fig. 92); (48-53) SEM images, (48) whole valve, (49) detail of internal view of pole, with rimoportula (arrow), (50) detail of external view of pole, with rimoportula and two over-hanging spines (arrows, either side of rimoportula), (51) external view of frustule with two valves and three closed girdle bands, $(52,53)$ detail of valvocopula showing 'poroids' along pars interior edge (arrows) and undulating edge for attachment to valve virgae. Specimens in Figs 44b-46, c. 100-120 $\mu \mathrm{m}$. Scale bars for Figs 48-53: 50 $\mu \mathrm{m}$ (48), $5 \mu \mathrm{m}(49,51,52,53), 1 \mu \mathrm{m}(50)$

Three Kützing slides in BM are identified as having specimens of Synedra aequalis: BM 18266, 18267 and 18268. No specific locality is mentioned in the description of Frustulia aequalis (see Fig. 28) but Weissenfels is later given for Synedra aequalis (see Fig. 29). Of the three slides noted above, only BM 18267 (KÜTZING 226) is from Weissenfels; BM 18266 (KüTZING 942) is from Tergesti [=Trieste], Italy, and BM 18268 (KüTZING 1581) is from Falaise, France. The material used to make slide BM 18267 was KÜTZING 226, which has been used for the SEM examinations; BM 18267 is also selected as a neotype. This requires some explanation as, some might argue, the illustrations in KüTZING (1833a, pl. 14, fig. 30 and the identical figures in KüTZING 1834 [1833], taf. II, fig. 30, reproduced as our Figs 22 and 28) are, if strictly interpreted, part of the type material and should thus be preferred as a designated lectotype.

Previously, REICHARDT (2018) outlined what he understood as several potentially inter-related problems with the name Synedra aequalis and the combination, made twice, Synedra ulna var. aequalis: first by BRUN (1880, p. 126, pl. 5, figs 2, 3, for his illustration see our Fig. 27), then by Hustedt (1914, p. 44 see also HustedT 1930, p. 152, fig. 164, for his illustration see our Fig. 
44b). Although HuSTEDT's 1914 combination is invalid, REICHARDT (2018) suggested that it was made on the basis of what was understood to be Synedra aequalis (as depicted in KüTZING 1844, pl. 14, fig. 14) rather than Frustulia aequalis (as depicted in KüTZING 1833a, pl. 14, fig. 30 and 1834 [1833], taf. II, fig. 30), the latter, according to REICHARDT, possibly being a species of Nitzschia ("HustedT begründet seine Kombination ausdrücklich auf Frustulia aequalis und nicht auf Synedra aequalis [...]. Seine Aussage "Sie bewegte sich" lässt zumindest darauf schließen", REICHARDT 2018, p. 100"). In the later 1932 flora, HustedT (1932) was more explicit about the synonymy: He maintained Frustulia aequalis as the basionym of his Synedra ulna var. aequalis, rejected Synedra aequalis ("Nec Synedra aequalis" as depicted in KüTZING 1844, pl. 14, fig. 14) as a synonym, but included Synedra obtusa (HuSTEDT 1932, p. 199, fig. 691Ad, see our Fig. 44a; this specimen has no central area unlike the earlier illustration in HUSTEDT 1930) and Synedra ulna var. calcarea Rochoux d'Aubert (in Heribaud 1920, p. 81, pl. 5, fig. 38²) as synonyms. Kützing's earlier illustrations were in girdle view (KüTZING 1833a, pl. 14, fig. 30 and 1834 [1833], taf. II, fig. 30) our Figure 22, possibly with chloroplasts) and, as Reichardt suggested, its interpretation is almost impossible and any conclusion meaningless ("Seine Abbildungen zeigen allerdings nur Gürtelansichten und sind deshalb nichtssagend", REICHARDT 2018, p. 100”). The specimens examined herein, while not being definitely holotype material, are almost as good, as they are from Weissenfels, the type locality, and it would be more useful to designate these specimens as a neotype rather than have a poor and ambiguously interpreted drawing as a lectotype, even though, as noted in noted in Art (9.19, note 7, Turland et. al. 2018), "illustrations are part of the protologue and cannot therefore be in serious conflict with it". While the drawing is difficult to interpret, it would not be in conflict, as any interpretation would suffice. Our taxonomic conclusions are that, following KüTZING (1844, p. 66, pl. 14, fig. 14), Frustulia aequalis should be considered the basionym of Synedra aequalis and, as a consequence, Ulnaria aequalis.

Is Ulnaria aequalis the same species as Synedra splendens, as both were found in Weissenfels and, with respect to their major features, do appear remarkably similar? For the moment, they are best left separate as Ulnaria aequalis has poles that taper more sharply than Synedra splendens and their valve margins remain parallel for longer as they approach each pole.

Nevertheless, the specimen figured in HustedT (1930, p. 152, fig. 164, reproduced as our Figure 44b) does indeed resemble valves of $U$. obtusa (see Figures 45-48) rather than those of $U$. aequalis. Therefore, the conclusions concerning the two combinations noted

2 No specimens of this taxon have been located but the single published image suggests that it might be worth investigating should any be found. above are as follows: Synedra ulna var. aequalis (Kütz.) Brun (BRUN 1880, p. 126, pl. 5, figs 2, 3) = Ulnaria aequalis; Synedra ulna var. aequalis (Kütz.) Hust. (HustedT 1930, p. 152, fig. 164) = Ulnaria obtusa. Of course, inspection of Hustedt's and Brun's specimens should always be preferred to a consideration of just a few illustrations, but in their absence this seems the most prudent action to take.

Finally, Cox examined a number of Kützing slides in BM for a study on naviculoid diatoms (Cox 1998, table 1, pp. 166-7). In her table 1 she lists BM 18267 as having specimens of Synedra aequalis, noting “det. R Patrick” meaning “determined by Ruth Patrick" (Cox 1998, table 1, pp. 167). This refers to an additional label on the slide that was added by Ruth Patrick after inspecting the slide in the early 1960s for the Diatoms of the United States (in PATRICK \& REIMER $1966^{3}$ ). In that flora, Patrick includes Frustulia aequalis as a synonym of Synedra ulna var. obtusa (W.Sm.) Van Heurck (VAN Heurck 1885, p. 151, 1881, pl. 38, fig. 6) but not Synedra aequalis (PATRICK \& REIMER 1966, p. 152). Patrick noted that "William Smith states his taxon is the same as specimens of Synedra aequalis Kütz. (KüTZING 1849, p. 45) sent to him by Brébisson ... [but] they are not the same as $S$. aequalis illustrated by KütZING (1844, p. 66, pl. 14, fig. 14)" (Patrick in PATRICK \& ReImer 1966, p. 152). Smith does indeed refer to Kützing's Synedra aequalis (by way of KüTZING 1849 , p. 45) and does refer to a specimen, "ad specim. quae dedit amic. De Brébisson” (SмIтн 1853, p. 71), yet comparison with specimens of Ulnaria obtusa from BM (Figs 45-46) with specimens from BR (Figs 54-57) suggest a few distinctions between Ulnaria aequalis and Ulnaria obtusa, which we discuss below.

\section{Ulnaria obtusa (W.Sm.) E.Reichardt 2018, p. 100}

Basionym: Synedra obtusa W.Sm. in Sмітн 1853, p. 71, pl. 11, fig. 92 Synonyms (homotypic): Synedra ulna var. obtusa (W.Sm.) Van Heurck in VAN HeUrCK 1881, pl. 38, fig. 6 [“...cum area media sublaevi”]; VAN HeURCK 1885, p. 151; Synedra ulna var. aequalis (Kütz.) sensu Hustedt 1914, p. 44 (Hustedt 1930, p. 152, fig. 164; Hustedt 1932, p. 199, fig. 691Ad)

Type: UK, "Lewes, Feb. 1852”, BM 23748-50 (Figures 45, 46, 48) Other material: UK: BR Kingston, 4.3.1853, Smith material in Van Heurck collection, BM 81919; "ad specim. quae dedit amic. De Brébisson” (SмIтн 1853, p. 71) (Figs 54-57): BR unmounted material of $S$. aequalis Kütz. in Van Heurck collection (Figs 48-53).

Valves linear with rounded poles (Figs 44-49, 54, 55, 57); valves 150-200 $\mu \mathrm{m}$ long, 5-8 $\mu \mathrm{m}$ wide. Sternum narrow, linear but prominent, extending length of valve (Figs 45-49, 54, 55, 57). Central area lacking (Figs 45, 46, 48, 54, 55, 57 - but present in REICHARDT (2018, pl. 23, fig. 5-7, 14), with evident 'ghost' striae). Striae formed from relatively wide virgae, adjoining considerably smaller vimines, enclosed by a $2-$ to $4-$ strutted

\footnotetext{
3 There is no date on the additional label added by Patrick so the exact date she examined these slides is unknown. No entry in the diatom collection visitors book is available.
} 
closing plate, almost always found opposite each other relative to sternum, except (occasionally) at poles (Figs $50,51)$; 3-4 striae in $10 \mu \mathrm{m}$. Rimoportula at each pole, diagonally situated from sternum to virgae, formed of paired lips (Figs 49, 50, 51, wide 49). Ocellulimbus at each pole, situated entirely on mantle, composed of ca. 12-15 transapical rows with 10-12 pervalvar rows, 2 horn-like projections ('spines', cf. WiLLIAMs 2019b) overhanging ocellulimbus, at an angle of $30^{\circ}$ away from valve surface (Figs 50, 51, arrows in Fig. 50 to spines). No other spines. Girdle bands closed (Figs 51, 52, 53, contrary to popular opinion, bands can appear visible in LM: Fig. 56), total of three, valvocopula plus two

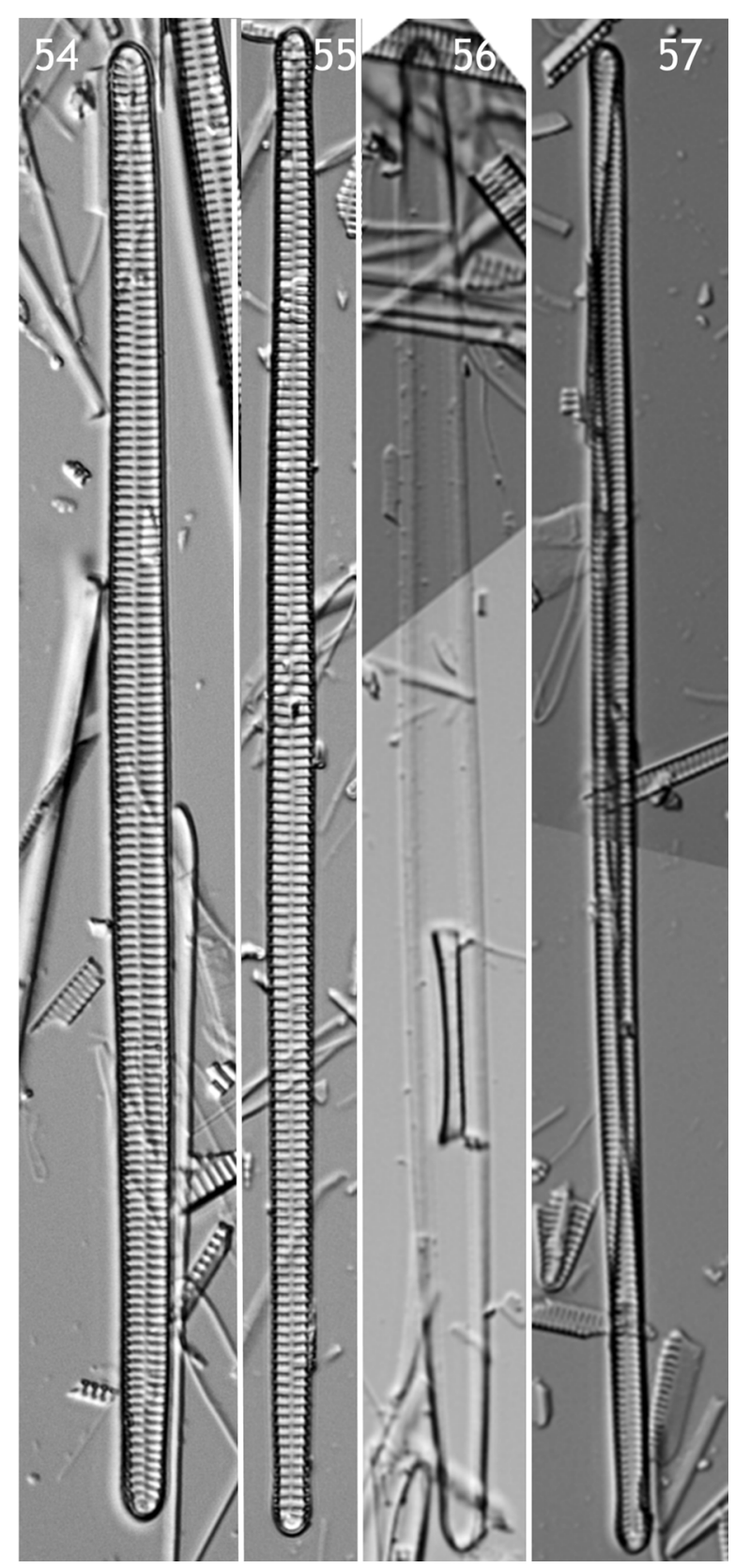

Figs 54-57. Ulnaria obtusa (W.Sm.) E. Reichardt: $(54,55)$ from BM 81919, "ad specim. quae dedit amic. De Brébisson" (SмIтн 1853, p. 71), $(56,57)$ from BR Kingston, 4.3 .1853 , Smith material in Van Heurck collection. Specimens c. $150 \mu \mathrm{m}$. copulae (Fig. 51). Valvocopula with deep pars interior, same size as pars exterior, the latter having a series of 6- to 10-strutted closing plates situated at its edge but visible when observed in situ (Figs 52, 53); pars interior smooth with undulating extensions that affix to valve interior gripping each vimen (Figs 52, 53, arrow in in Fig. 52 for closing plates, upper arrow in Fig. 53 for pars interior, lower arrow for closing plates).

We noted above some difficulties with the names of Ulnaria obtusa and Ulnaria aequalis. A short digression is needed to account for some of Smith's determinations. In BM there is a copy of SMITH (1859) that was once owned and annotated by THOMAs GLAZEBROOK RYLANDS (1818-1900). In an insert before the printed page that included the description of Synedra salina, Rylands writes:

Synedra salina - I consulted $\mathrm{M}^{\mathrm{r}}$. Tuffen West about this species when at his house, and he said: "I must consider myself responsible to a great extent for the Synedra's in the Synopsis. Smith confessed that he could make nothing of them. He sent all the materials to me telling me to draw what I considered distinct. I did so and he worked from my drawings" (SMITH 1859, page inserted after p. 30 and before p. $31^{4}$ )

In Smith's Catalogue only "Lewes, Feb. 1852” (“In ponds. Not uncommon") is listed (SмIтн 1859, p. 32), the type, and only, locality given in SMITH (1853, p. 72). There are three slides in BM: BM 23748-50, which can be assumed type specimens. Slides BM 23749 and 23750 are both labelled as types; the latter was used for the images in Figures 45, 46, 48.

Smith also noted under the description "Synedra ulna, Ehr. Inf. xvii. 1? S. aequalis, Kütz. Sp. Alg. p. 45 ad specim. quae dedit amic. de Brébisson" (Sмiтh 1853, p. 71). The illustration in EHRENBERG (1838, pl. xvii, fig. 1) could be interpreted as a number of species, not all necessarily belonging to Ulnaria. The De Brébisson specimens given to Smith ("ad specim. quae dedit amic. De Brébisson") were located in BR and used for the SEM images in this paper.

In the synonymy for Ulnaria obtusa, Reichardt includes Synedra ulna var. aequalis (Kütz.) Hust. (HusteDT 1914, p. 44) but not Synedra ulna var. aequalis (Kütz.) Brun (BRUN 1880, p. 126, pl. 5, figs 2, 3, our Fig. 6), an act with which we agree. Hustedt published two figures (1930, p. 152, fig. 164, reproduced as our Fig. 44b and Hustedt (1932, p. 199, fig. 691aD), reproduced as our Fig. 44a). It is evident, even from a comparison of these two illustrations with Smith's original for Synedra obtusa (SмIтH 1853, pl. 11, fig. 92, reproduced as our Fig. 47), that they all differ from both Synedra aequalis

4 This copy is kept in the BM diatom library: call number 'Diatoms 582.261 (410) SMI'. There are three copies in all. The RYLANDS annotated copy in bound in brown buckram with BM(NH) stamps on the spine. 
and from Synedra ulna var. aequalis (Kütz.) Brun, as Hustedt noted (HustedT 1914, p. 44-5), but not from Ulnaria obtusa of which they are examples.

\section{Discussion}

As noted in our introduction, given that there is no agreed definition of what a variety (or form) might mean nor what its status is - if anything - in systematics, the rank is unclear and ambiguously used, even today (but see GEISSLER \& JAHN 1986, p. 767 for a brief discussion, albeit from the rather antique 'deme' terminology point of view). Viewed from the general perspective of taxa (at whatever rank, see WiLLIAMs 2020) and their hierarchical relations one to another, with some justification (perhaps the only justification), one might assume that all named varieties of Ulnaria splendens (or whatever species is in question) are presumed to be more closely related amongst themselves than they are to any other species until such times as is shown otherwise. One might also assume that all the named varieties of Ulnaria splendens are, or were, supported by evidence of some kind, otherwise the introduction of these names would have been merely idiosyncratic (e.g. EvenHUIs 2008; DuBoIs 2008), a not completely discountable interpretation. Having inspected type material for a number of these taxa, we have concluded that Ulnaria splendens, Ulnaria aequalis and Ulnaria obtusa are all definable and diagnosable taxa, but none can be considered as more closely related to any other species in the genus Ulnaria and are therefore recognised at the same rank, that of species.

As we noted above, it is almost impossible to assess the distribution of any of these species discussed herein as so many specimens and names have been mixed up together and used in different senses (see also LANGE-Bertalot \& UlRich 2014, p. 64). Nevertheless, it is all too obvious that the European flora has many more species of Ulnaria hidden away, yet to be described. Regardless of the promises offered by DNA data, the only way forward to gain an understanding of these organisms is to monograph the genus Ulnaria, utilising the vast numbers of specimens already acquired and housed in various herbaria around the world. That task is currently underway.

To close, we briefly discuss five further taxa (names) that involve the name Synedra splendens requiring some comment. The first two are Synedra splendens var. marina Grunow (in CLEVE \& MöLLER 1878, p. 7, no. 157, Lysekil, Bohuslän, Sweden, BM 12917, AdAMs Cl. \& M. 157; also S122856-01 [Swedish Museum of Natural History], Lysekil, Sweden, isotypes, and elsewhere) and Synedra splendens var. salina Cleve et Möller (CLEve \& MöLler 1879, p. 3, no. 197, Baakens River, Port Elizabeth, South Africa, BM 12940, ADAMS Cl. \& M. 197, isotypes). In both cases, only the names are
58

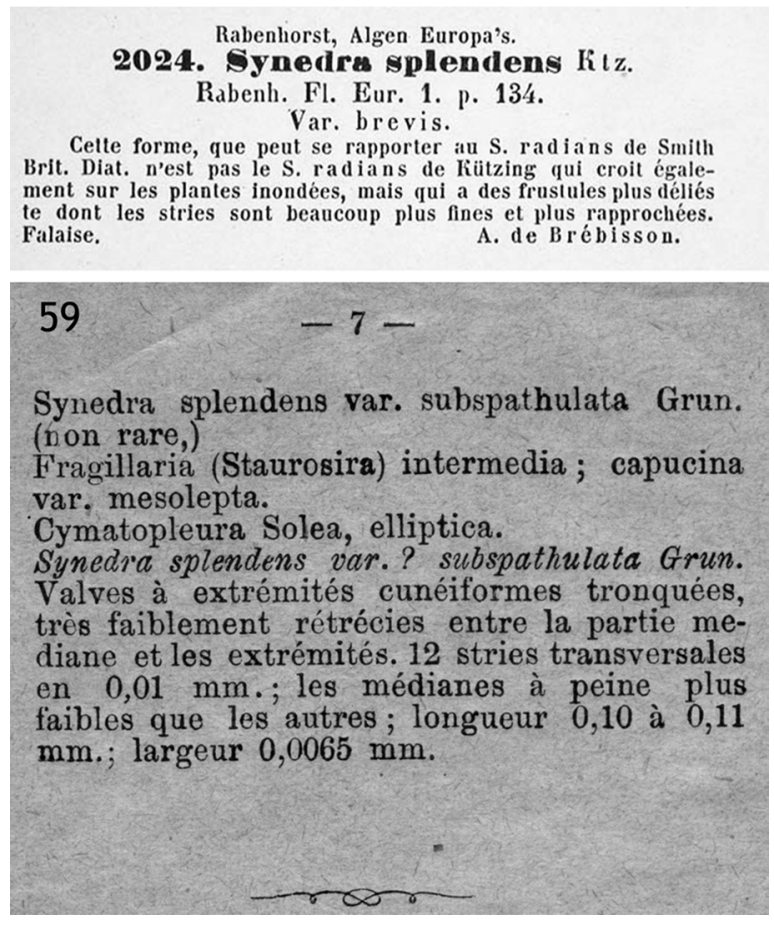

Figs 58-59. (58) Synedra splendens var. brevis, Rabenhorst's Die Algen Europa's 2024 (RABENHORST 1867a); (59) original description of Synedra splendens var. subspathulata Grunow from slide no. 25 in Van Heurck's Types du Synopsis des Diatomées de Belgique (Heurck 1882, p. 7).

recorded in the schedules for these slides, neither having a description of any kind and appear to have never been validly published anywhere else. Both are marine (Cleve \& Möller suggest that Synedra splendens var. salina may be equivalent to Synedra salina, "S. salina Sm. ??", ClEve \& MöLler 1879, p. 3) and neither name seems to have been used again since their first publication in Cleve \& Möller's Diatoms (CLEVE \& MöLlER 1877-1882). A glance at the specimens on the two Cleve \& Möller slides in BM suggests they both probably belong to the genus Hyalosynedra D.M.Williams et Round but this needs further study, especially with the SEM.

The third name is Synedra splendens var. brevis, which appeared on the label of number 2024 of Rabenhorst's Die Algen Europa's (RABENHORST 1867a, see Fig. 58). A brief account of some taxa found in Rabenhorst's Die Algen Europa's Decades 198-204 was published in Hedwigia, with Synedra splendens var. brevis attributed to de Brébission (RABENHORST 1867b). It may be that the name was never intended to indicate a proper taxonomic entity just an additional descriptive word (brevis $=$ short) but the Hedwigia account suggests otherwise. The material was from Falaise, the collector was de Brébisson. As yet, specimens have not been examined.

The fourth name is Synedra splendens var. subspathulata Grunow which was first described from specimens on slide no. 25 in the schedule for series I (for 
the first 25 slides) of Van Heurck's Types du Synopsis des Diatomées de Belgique (HeurcK 1882, p. 7, see Figure 59). Later, VAN HeURCK (1881, pl. 38, fig. 4) published an illustration of a specimen Grunow named (but did not describe) as Synedra (ulna var.) spathulifera Grunow from Alnarp (Sweden) based on a sample from Cleve. Subsequent authors used the name Synedra spathulifera Grunow, which later became Ulnaria ulna var. spathulifera (Grunow) Aboal (in ABOAL et al. 2003, p.114). This is our fifth name. A brief description of it appeared in the 'texte' of the Synopsis des Diatomées de Belgique (VAN HeUrCK 1885, p. 151), apparently based on "Type No. 25" and "Atl. Pl. XXXVIII, fig. 4", slide no. 25 being the source of Synedra splendens var. subspathulata, the figure for Synedra (ulna var.) spathulifera. Do these two names refer to the same taxon? This issue has been briefly tackled by HowARD et al. (2019) - a more detailed account will follow when the Grunow material has been verified.

\section{ACKNOWLEDGEMENTS}

Synthesys grant BE-TAF-1396 allowed DMW to visit BR to examine some William Smith and Kützing material related to the data in this paper. We are grateful to David Lazarus and Edgley Cesar for examining specimens of Synedra splendida Ehrenberg in Berlin (BHUPM) and to an anonymous referee for many useful comments, particularly in relation to nomenclature. As ever, Luc Ector helped immensely with obtaining difficult to find literature.

\section{REFERENCES}

Aboal, M.; Alvarez Cobelas, M.; Cambra, J. \& Ector, L. (2003): Floristic list of non-marine diatoms (Bacillariophyceae) of Iberian Peninsula, Balearic Islands and Canary Islands. Updated taxonomy and bibliography. - Diatom Monographs 4: 1-639.

BRUN, J. (1880): Diatomées des Alpes et du Jura et de la région Suisse et Française des Environs de Genève. - 146 pp., 9 pls., Imprimerie Ch. Schuchardt, Genève.

Cantonati, M.; Kelly, M.G. \& Lange-Bertalot, H. (2017): Freshwater Benthic Diatoms of Central Europe: Over 800 Common Species Used in Ecological Assessment. - 942 pp., Koeltz Scientific Books, Schmitten-Oberreifenberg.

CoMpère, P. (2001): Ulnaria (Kützing) Compère, a new genus name for Fragilaria subgen. Alterasynedra LangeBertalot with comments on the typification of Synedra Ehrenberg. - In: JAHN, R., KocIOLEK, J.P., WITKOwSKI, A. \& COMPÈre, P. (eds): Lange-Bertalot-Festschrift: Studies on Diatoms. Dedicated to Prof. Dr. Dr. h.c. Horst Lange-Bertalot on the occasion of his 65th Birthday. - pp. 97-102, A.R.G. Gantner Verlag. K.G.

Cleve, P.T. \& Möller, J.D. (1878): Diatoms. Part III, No. 109-168. - Esatas Edquists Boktryckeri, Upsala.

Cleve, P.T. \& Möller, J.D. (1879): Diatoms. Part IV, No. 169-216. - Esatas Edquists Boktryckeri, Upsala.

Cleve, P.T. \& Möller, J.D. (1877-1882): Diatoms. - Esatas Edquists Boktryckeri, Upsala.

Cox, E.J. (1998): The identity and typification of some naviculoid diatoms (Bacillariophyta) from freshwater or brackish habitats. - Phycologia 37: 162-75.

De Toni, G.B. (1892): Sylloge algarum omnium hucusque cognitarum. Vol. II. Bacillarieae; sectio II. Pseudoraphideae.
- pp. 491-817, Typis Seminarrii, Patavii.

Dubois, A. (2008): A partial but radical solution to the problem of nomenclatural taxonomic inflation and synonymy load. - Biological Journal of the Linnean Society 93: 857-863.

EHRENBERG, C.G. (1830): Organisation, Systematik und geographisches Verhältniss der Infusionsthierchen. - 108 pp., Zwei verträge. Abhandlungen der Königlichen Akademie der Wissenschaften zu Berlin.

EHRENBERG, C.G. (1838): Die Infusionsthierchen als vollkommene Organismen. Ein Blick in das tiefere organische Leben de Natur. - pp. i-xvii, 1-548, pls. 1-64, Verlag von Leopold Voss, Leipzig.

EhrenBerG, C.G. (1849a): Über das mächtigste bis jetzt bekannt gewordene (angeblich 500 Fuss mächtige) Lager von mikroskopischen reinen kieselschaligen Süsswasser-Formen am Wasserfall-Flusse im Oregon. - Bericht über die zur Bekanntmachung geeigneten Verhandlungen der Königlich-Preussischen Akademie der Wissenschaften zu Berlin1849: 76-87 http://biodiversitylibrary.org/page/11053716 [Partial translation in: EhrenBerg, C.G. (1850): On Infusorial Deposits on the River Chutes in Oregon. - American Journal of Science 2nd ser, 9, p. 140.]

EHRENBERG, C.G. (1849b): Über ein infusorienhaltiges Gypslager in Klein-Asien. - Bericht über die zur Bekanntmachung geeigneten Verhandlungen der Königlich-Preussischen Akademie der Wissenschaften zu Berlin 1849: 193-195. [http://biodiversitylibrary.org/page/11053716 [Partial translation in: EHRENBERG, C.G. (1850): On Infusorial Deposits on the River Chutes in Oregon. - American Journal of Science 2nd ser., 9, p. 140]

EhrenBerG, C.G. (1871): Über die wachsende Kenntnis des unsichtbaren Lebens als felsbildende Bacillarien in Californien. - Abhandlungen der Königliche Akademie der Wissenschaften zu Berlin 1870, 43: 1-73, pls 1-3.

Evenhuis, N. (2008): The "Mihi itch"-a brief history. - Zootaxa 1890: 59-68.

GeISSLER, U. \& JAHN, R. (1986): Infraspecific taxa of diatoms as indicators of water quality? - In: RiCARD, M. (ed.): Proceedings of the 8th International Diatom Symposium, Paris, 1984 - pp. 766-772. BioPress, Bristol.

GRunOw, A. (1862): Die österreichischen Diatomaceen nebst Anschluss einiger neuen Arten von andern Lokalitäten und einer kritischen Uebersicht der bisher bekannten Gattungen und Arten. Erste Folge. Epithemieae, Meridioneae, Diatomeae, Entopyleae, Surirelleae, Amphipleureae. - Verhandlungen der KaiserlichKöniglichen Zoologisch-Botanischen Gesellschaft in Wien 12: 315-472.

Héribaud, J. [Avec la collaboration de F. Azpeitia, Comère, Deblock, E. Ostrup, M. Peragallo, P. Prudent \& A. Rochoux D'AuberT] (1920): Les Diatomées des travertins d'Auvergne. - Annales de Biologie Lacustre 10: [5]-206 [and: HéRIBAUD, J. (1920): Les diatomées des travertins d'Auvergne (Avec la collaboration de F. Aspeitia, Comère, DebloK, E. Østrup, M. Peragallo, P. Prudent, A. Rochoux D’Aubert). Bruxelles, 206 pp.]

HollerbakH, M.M. \& Krasavina, L.K. (1971): Vodorosli svodnyi Ukazatel k otechestvernnym Bibliografiyam po vodoroslyam za 1737-1960 gg. - 723 pp., Akademiya Nauk S.S.S.R., Leningrad.

Howard, K.; Wu, S.; Dong, K.; Lee, S. \& Van de ViJver, B. (2019): Ulnaria cf. spathulifera from Burnt Cedar Beach, Lake Tahoe, Nevada. - In: $25^{\text {th }}$ North American 
Diatom Symposium proceedings, July 31-Aug 4, 2019. - Eatonton, GA.

Hustedt, F. (1914): Bacillariales aus den Sudeten und einigen benachbarten Gebieten des Odertales. - Archiv für Hydrobiologie und Planktonkunde 10: 1-128.

Hustedt, F. (1930): Bacillariophyta (Diatomeae). -In: PASCHER, A. (ed.): Die Süsswasser-Flora Mitteleuropas, Heft 10. - 466 pp., 875 figs., Gustav Fischer, Jena. Zweite Auflage.

Hustedt, F. (1932): Die Kieselalgen Deutschlands, Österreichs und der Schweiz unter Berücksichtigung der übrigen Länder Europas sowie der angrenzenden Meeresgebiete. - In: RaBENHORST, L. (ed.): Kryptogamen Flora von Deutschland, Österreich und der Schweiz 7: 177-320.

KÜTZING, F.T. (1833a): Synopsis Diatomacearum oder Versuch einer systematischen Zusammenstellung der Diatomeen. - Linnaea 8: 529-620.

KÜTZING, F.T. (1833b): Algarum Aquae Dulcis Germanicarum. - Halis Saxonum in Commissis C.A. Schwetschkii et Fil.

KÜTZING, F.T. (1834 [1833]): Synopsis Diatomearum oder, Versuch einer systematischen Zusammenstellung der Diatomeen. - 92 pp., Halle: Schwetschke.

KüTZING, F.T. (1844): Die Kieselschaligen. Bacillarien oder Diatomeen. - 152 pp., 30 pls.Nordhausen.

KÜTZING, F.T. (1849): Species Algarum. - 922 pp., F.A. Brockhaus, Lipsiae.

LANGE-Bertalot, H. \& UlRich, S. (2014): Contributions to the taxonomy of needle-shaped Fragilaria and Ulnaria species. - Lauterbornia 78: 1-73.

NitzsCH, C.L. (1817): Beitrag zur Infusorienkunde oder Naturbeschreibung der Zerkarien und Bazillarien. Neue Schriften der naturforschenden Gesellschaft zu Halle 3: viii, 128 pp., 6 pls.

Patrick, R.M. \& Reimer, C.W. (1966): The Diatoms of the United States exclusive of Alaska and Hawaii. Volume 1. Fragilariaceae, Eunotoniaceae, Achnanthaceae, Naviculaceae. - Monographs of the Academy of Natural Sciences of Philadelphia 13: 688 pp., 64 pls.

Proschkina-Lavrenko, A.I. \& Roll, J.V. (1927): Predvaritelnye svedeniya o mikroflore reki Kazennogo Tortsa u g. Slavyanska. Chast II (Bacillariaceae). - pp. 115-129, Naukovi Zapiski po Biologii, Kh'arkov.

Ptschelin, N. (1930): Lac de Sakky, son origine et ses richesses servant aux traitement des maladies. - KurortnoSanatornoje Dielo, Moscou 8: 42-50 [Not seen]

RABENHORST, L. (1853): Die Süsswasser-Diatomaceen (Bacillarien) für Freunde der Mikroskopie. - 72 pp., Leipzig: E. Krümmer.

Rabenhorst, L. (1855): Die Algen Sachsens. Resp. MittelEuropa's Gesammelt und herausgegeben von Dr. L. Rabenhorst. - Decades 47-48. Dresden.

Rabenhorst, L. (1858): Die Algen Sachsens. Resp. MittelEuropa's Gesammelt und herausgegeben von Dr. L. Rabenhorst. - Decades 69-70. Dresden.

RABENHORST, L. (1864): Flora Europaea Algarum aquae dulcis et submarinae. Sectio I. Algas diatomaceas complectens, cum figuris generum omnium xylographice impressis. -359 pp., Apud Eduardum Kummerum, Lipsiae,

RABENHORST, L. (1867a): Die Algen Europa's, fortsetzung der Algaen Sachsens resp. Mittel-Europa's. - Decas 101-104. Dresden.

RABENHORST, L. (1867b): Algen Europa's. Decas 198-204. Dresden 1867. - Hedwigia 11: 170-172.

Sмiтh, W. (1859): List of the British Diatomaceae in the Collection of the British Museum. - 55 pp., Taylor \&
Francis, London.

Smith, W. (1853-6): Synopsis of British Diatomaceae, Vol. 1, Vol. 2. - 89 pp., 107 pp., John Van Voorst, London Turland, N. J.; Wiersema, J. H.; Barrie, F. R.; Greuter, W.; Hawksworth, D. L.; Herendeen, P. S.; KnapP, S.; KusBer, W.-H.; LI, D.-Z.; MARhold, K.; MaY, T. W.; McNeill, J.; Monro, A.M.; Prado, J.; Price, M. J. \& SмITH, G. F. (eds.) (2018): International Code of Nomenclature for algae, fungi, and plants (Shenzhen Code) adopted by the Nineteenth International Botanical Congress Shenzhen, China, July 2017. - Regnum Vegetabile 159, Glashütten, Koeltz Botanical Books. DOI: https://doi.org/10.12705/Code.2018

VAN DEN BosCH, R.B. (1846): Enumeratio plantarum Zeelandiae belgicae. - Nederlandsch kriudkundig archief 1: 84-115.

Van Heurck, H. (1880): Synopsis des Diatomées de Belgique. - pls. 1-30, Atlas. Ducaju \& Cie., Anvers.

VAn Heurck, H. (1881): Synopsis des Diatomées de Belgique. - pls. 31-77, Atlas. Ducaju \& Cie., Anvers.

Van Heurck, H. (1882): Types du Synopsis des Diatomées de Belgique. - Sér. I (slides 1-25).

Van Heurck, H. (1885): Synopsis des Diatomées de Belgique. - 120 pp., Table Alphabétique (Index). J.F. Dieltjens, Anvers.

VanLandingham, S.L. (1978): Catalogue of the fossil and recent genera and species of diatoms and their synonyms. Part VII. Rhoicosphenia through Zygoceros. - Lehre, Verlag von J. Cramer 7: 3606-4241.

Williams, D.M. (1986): Comparative morphology of some species of Synedra with a new definition of the genus. - Diatom Research 1: 131-152.

Williams, D.M. (2011): Synedra, Ulnaria: definitions and descriptions - a partial resolution. - Diatom Research 26: $149-153$.

WiLLIAMS, D.M. (2019a): Studies on type material from Kützing's diatom collection I: Synedra vitrea Kützing, with comments on Ulnaria fragilariaeformis (F.E.Fritsch and M.F.Rich) D.M.Williams, nov. stat. et nov. comb. and Ulnaria undulata (Rabenhorst) D.M. Williams, nov. stat. et nov. comb. - Botany Letters 167: 70-85.

WiLliams, D.M. (2019b): Spines and homologues in 'araphid' diatoms. - Plant Ecology and Evolution 152: 150-162. DOI: $10.5091 /$ plecevo.2019.1597.

WiLliams, D.M. (2020): Diatom classifications: What purpose do they serve? - In: Cristobal, G.; Blanco, S. \& Bueno, G. (eds): Modern Trends in Diatom Identification: Fundamentals and Applications. - pp. 11-24, Springer Nature Switzerland AG, Cham, Switzerland.

Williams, D.M. \& Blanco, S. (2020): Studies on type material from Kützing's diatom collection II: Synedra acus Kützing, Synedra arcus Kützing, their morphology, types and nomenclature. - Diatom Research 34: 237-250.

Williams, D.M. \& KARTHICK, B. (2021): The correct use of the names Synedra Ehrenberg and Catacombas Williams $\&$ Round, a note on the name 'Hystrix Bory 1822', and some suggestions how to tackle the taxonomic relationships of Synedra. - Diatom Research. DOI: https://doi.org/10.1080/0269249X.2021.1880974.

(C) Czech Phycological Society (2021)

Received October 28, 2020

Accepted March 23, 2021 